\title{
高速フレーム溶射プロセスに及ばす 燃焼ガスジェットの膨張状態の影響
}

\author{
榊 和彦 清水保雄 合田祥昭†
}

信州大学工学部機峨システム工学科

J. Japan Inst. Metals, Vol. 63, No. 2 (1999), pp. 269-276

\section{Effect of Expansion State of Combustion Gas Jet on High Velocity Oxygen-Fuel Thermal Spraying Process}

\author{
Kazuhiko Sakaki, Yasuo Shimizu and Yoshiaki Gouda ${ }^{\dagger}$
}

Department of Mechanical Systems Engineering, Faculty of Engineering, Shinshu University, Nagano $380-8553$

\begin{abstract}
The Effect of expansion state of combustion gas jet on high velocity oxygen-fuel thermal spraying process was investigated using a diverging gun nozzle exit by numerical simulation and experiments with spray powder of Ni-17 mass \% Cr-6\%Al-0.5\% Y. Two different nozzle shapes with a constant throat diameter, namely (i) a convergent-barrel type available in the market and (ii) a convergent-barrel-divergent type, were used. The convergent-barrel-divergent nozzles were designed in such a way that the $15 \mathrm{~mm}$ divergent part length had a minimum effect, so that only the effect of expansion state of combustion gas jet was investigated. Numerical simulation studies were carried out by assuming the gas flow within the nozzle to be a quasi-one-dimensional isentropic flow of a semi-perfect gas.

The numerical simulation results showed a decrease in temperature and density and an increase in velocity of the gas with the diverging nozzle exit, but its effect on the spraying particle behavior was very little.

Experimental results showed that the expansion state of combustion gas jet changed from under-expansion to correct-expansion, to over-expansion with increasing nozzle exit diameter. Among them, the particle velocity at a spray distance of $200 \mathrm{~mm}$ reached a maximum with correct-expansion state of the gas jet due to an increased gas jet velocity. This resulted in an increase in the bonding strength of the $\mathrm{NiCrAlY}$ coating. However, the effect of the expansion state of the jet on the structure, hardness and degree of oxide content of the coatings was little. Also, the deposition efficiency of the coatings was found to increase with the increase in the nozzle exit diameter.
\end{abstract}

(Received July 24, 1998; In Final Form October 13, 1998)

Keywords: high velocity oxygen-fuel thermal spraying, expansion state of combustion gas jet, nozzle geometry, diverging gun nozzle exit, particle velocity, coating quality

\section{I. 緒言}

溶射技術の歴史の中で，プラズマ溶射法以降の画期的な技 術として高速フレーム溶射法(以下, HVOF 溶射 : High Velocity Oxygen-Fuel Thermal Spraying, と略記する.)が 開発された。HVOF 溶射は粒子の飛行速度を増大させて, 皮膜の密度や密着性などの特性を向上させることに特徵があ る(1)-(3).

HVOF 溶射は，一般に然焼室とそれに連なるノズルから 構成されるガンを持ち，大量の酸素扣よび然料(可然がスま たは灯油）を高圧で然焼室に供給・燃焼させ，その燃焼がス を超音速フレームとしてノズルより噴出させる。溶射材料粒

$\ddagger$ 信州大学大学院生, 現在 : 三菱重工業秼)(Graduate Student, Shinshu University, Present address: Mitsubishi Heavy Industry Co.)
子の加速, 加熱, 軟化溶融, 酸化, 分解などの諸物理現象は フレーム中で非常に短時間で起こり，その後の素地への衝 突，扁平化，凝固，積層などの皮膜形成プロセスにも様々な 影響を及ぼす。したがって，フレームの流れとその中での粒 子の挙動は，HVOF 溶射法にとりきわめて重要な因子とな る.

フレームの高速化は，大量の燃料々酸素を燃焼させて燃焼 圧を上げる方法(1)と其に，適切なノズル形状を使用すること で達成される。たとえば，听トモーター(4)やガス溶断装 置(5)などでは，圧縮性流体力学を適用した先細末広ズル (ラバルノズル(6)）を用いて超音速流れを実現している。こ れらの場合, 最適とされるジェットの状態は, 不可逆変化を 生じず推力が最大となる適正膨張であり，ノズルの寸法・形 状はこの状態を実現できるよらに設計されている，一方， HVOF 溶射装置の現状をみると, 各社各様の形状のノズル が用いられて括り(7)，ラバルノズルも採用例はあるが，それ 
らノズルの設計の詳細は明らかにされていない。また， HVOF 溶射のノズル形状に関する研究報告も少なく, Hackett ら ${ }^{(8)}$ がノズルの末広化によりフレームを適正膨張流 れにできることを報告しているものの，それが溶射粒子や皮 膜特性に及ぼす影響については検討されていない。また，一 般に HVOF 溶射の運転条件は，燃燒フレームが不足膨張状 態，いわゆるショックダイアモンドが多数観察される状態が 最適であるかのように見なされている場合があるが，実際に は然焼压を高くすることに伴らノズル出口圧力の上昇により 不足膨張が強まったための結果であり，その解䅐は正しとは いえない。

筆者らは，これまでHVOF 溶射に扎いてノズル出口部の 末広化が，フレームと溶射粒子の挙動と皮膜特性に及ぼす影 響について，実験とノズル内の数值シミュレーションにて検 討してきた(9)-(12). その結果，ノズル出口部の末広化は，フ レームの速度をノズル内で超音速化し，その盜度と密度を低 下させ ${ }^{(9)}$ ，それにより溶射粒子を幾分増速し，溶融の度合い を下げることを明らかにしてきた。また，ノズル末広部長さ が大さくなるにつれて，これらの傾向が顕著になった(11).

しかし，皮膜特性に影響を及列すノズル末広化に伴らフレー ムの膨張状態の変化に的を絞って，その影響を明らかにする には至っていない。

よって，本報ではノズル末広部長さを比較的短く抑え，フ レームの膨張状態が溶射粒子の挙動々皮膜特性に及ぼす影響 Kついて，NiCrAlY 合金溶射粉末を用いた実験と数值シミ ュレーションに基づき検討する.

\section{II. 実 験 方 法}

\section{1. 溶射装置と溶射条件}

Fig. 1 K使用した HVOF 溶射装置 (Cabot Stellite 社 JET KOTE TMII)のガンの概略図を示京．本装置は，然焼室と， ズルの中心軸が約 $90^{\circ}$ をす構造を有している．溶射材料粉 末はノズル入口部後方からノズル中心軸上に搬送ガスととも

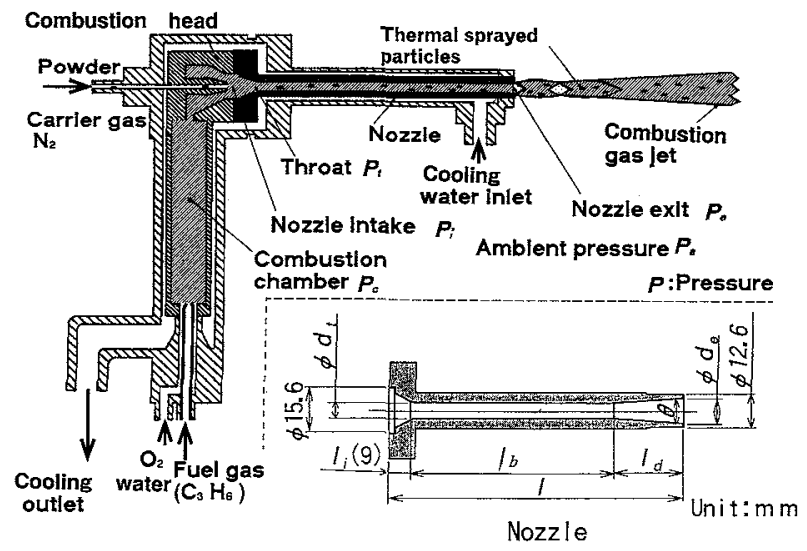

Fig. 1 Schematic diagram of HVOF (JET KOTE TM II) spraying gun and nozzle.
に然焼ガス内に投入される。

溶射は，市販の褐色アルミナ研削材（\#36）によるブラス ト処理の後，ア七トンによる超音波洗浄を施した基材に Table 1 示す条件で行った。ここで, 燃料扣よび酸素の流量 は，本装置では最高出力に近い代表的な 1 条件のみとした。

溶射材料は，高温耐食性皮膜として使用される市販の Ni17 mass $\% \mathrm{Cr}-6$ mass $\% \mathrm{Al}-0.5$ mass $\% \mathrm{Y}$ 合金 (NiCrAlY 合金 : 昭和電工侏製，SHOCOAT MA-90：粒径 $10 \sim 38 \mu \mathrm{m}$, 球形 のガスアトマイズ粉末)を用いた。

\section{2. ガンノズル}

ガンノズルは，Fig. 1 执よび Table 2 に示すよらに，市販 品と同じ寸法形状の先細円筒ノズル (以下, 円筒ノズルと呼 称し; Straight-7.8と記す)と，この円筒ノズル出口部を末 広化しとの末広部長さ $l_{\mathrm{d}}$ を一定として，燃焼がス噴流の膨 張状態を变化させるために出口径 $d_{\mathrm{e}}$ を変化させた 5 種類の 先細円筒末広ノズル（以下，末広ノズルと呼称し; Div. 末 広角 $\theta$-のど径 $d_{\mathrm{t}}$-出口 $d_{\mathrm{e}}$ の数值を添記して表示する)を使用 した。ここで， $l_{\mathrm{d}}$ 心，流れがはく離しないよらに末広角 $\theta$ を 比較的小さくする目的括よび $l_{\mathrm{d}}$ の影響を最小にするため 15 $\mathrm{mm}$ とし，また $d_{\mathrm{e}}$ はノズル設計上から適正膨張が得られる $9.12 \mathrm{~mm}^{(9)}$ 付近で変化させた.

\section{3. フレームジェットの観察と評価}

大気生が $0.098 \pm 0.001 \mathrm{MPa}$ の範囲内となる日時を選び， 溶射粉末を供給しない状態で，各ノズルょり噴出した燃焼ガ スフレームの膨張状態を写真おっよ゙゙目視により評価した。

\section{4. 飛行粒子挙動の測定法 ${ }^{(13)}$}

溶射ガンから基材に向かい飛行している溶射粒子の速度， 表面温度および粒径の測定は，粒子の高温放射光を利用する 溶射粒子挙動感知評価装置 (TECNAR 社 DPV-2000) 飞て解 析した. Fig. 2 にこの装置の検出へッド部の概略を示す. 溶射粒子の放射光は, 検出へッド部の中の特殊レンズと二つ のスりットを持つマスクを通り，光ファイバーを介して装置 本体に伝えられる。ここで，特殊レンズは溶射フレーム中の 微少領域のみに焦点を合わせて扣り，この領域を通過する溶 射粒子の放射光のみを検出でさる。速度は，二つのスリット

Table 1 Spraying system and conditions.

Spraying system: Jet Kote TM II (CABOT STELLITE)
Nozzle length: $76.2 \mathrm{~mm}$
Fuel/oxygen flow rate $\left(\mathrm{C}_{3} \mathrm{H}_{6} / \mathrm{O}_{2}\right): 90 / 486 \mathrm{~L} / \mathrm{min}$ [normal]
Carrier gas $\left(\mathrm{N}_{2}\right): 35 \mathrm{~L} / \mathrm{min}[$ normal]
Sprayed powder: NiCrAIY alloy
Powder feed rate: $7.7 \mathrm{~cm}^{3} / \mathrm{min}$ (NiCrAlY alloy: $55 \mathrm{~g} / \mathrm{min}$ )
Gun cooling water flow rate: $484 \mathrm{~g} / \mathrm{s}$
(Heat loss due to cooling water: $4.4 \mathrm{~kJ} / \mathrm{s}$ )
Gun traverse speed: $100 \mathrm{~mm} / \mathrm{s}$ (for pattern: $25 \mathrm{~mm} / \mathrm{s}$ )
Gun traverse pitch: $5 \mathrm{~mm}$
Spray distance: $200 \mathrm{~mm}$
Substrate: SUS304, SS400
Nozzle length: $76.2 \mathrm{~mm}$ [normal] Powder feed rate: $7.7 \mathrm{~cm}^{3} / \mathrm{min}$ (NiCrAlY alloy: $55 \mathrm{~g} / \mathrm{min}$ ) Gun cooling water flow rate: $484 \mathrm{~g} / \mathrm{s}$

Gun cooling wae to cooling water: $4.4 \mathrm{lJ} / \mathrm{s})$ Gun traverse pitch: $5 \mathrm{~mm}$ Substrate: SUS304, SS400 
Table 2 Shape and size of the gun nozzle used and the state of combustion gas stream.

\begin{tabular}{|c|c|c|c|c|c|c|c|c|c|c|c|c|c|c|c|c|c|c|}
\hline \multicolumn{8}{|c|}{ Shape and size of gun nozzle } & \multicolumn{11}{|c|}{ State of combustion gas stream } \\
\hline & Nozzle & $\theta^{* 3}$ & $\begin{array}{c}d_{\mathrm{t}} \\
\mathrm{mm}\end{array}$ & $\begin{array}{c}d_{\mathrm{e}} \\
\mathrm{mm}\end{array}$ & $\stackrel{l}{\mathrm{~mm}}$ & $\underset{\mathrm{mm}}{l_{\mathrm{b}}}$ & $\underset{\mathrm{mm}}{l_{\mathrm{d}}}$ & $\begin{array}{c}P_{\mathrm{i}}^{* 3} \\
\mathrm{MPa}[\mathrm{abs}]\end{array}$ & $\begin{array}{c}P_{e}^{*_{4}} \text { abs } \\
\mathrm{MPa}[\mathrm{abs}]\end{array}$ & $\begin{array}{l}U_{g 84}^{* 4} \\
\mathrm{~m} / \mathrm{s}\end{array}$ & $\begin{array}{c}U_{\mathrm{ge}}^{*_{4}} \\
\mathrm{~m} / \mathrm{s}\end{array}$ & $\underset{\mathrm{c}}{\mu_{l}}$ & $\underset{\mathrm{o}}{\beta}$ & $M^{* 5}$ & $\begin{array}{c}a_{\mathrm{e}} \\
\mathrm{m} / \mathrm{s}\end{array}$ & $\begin{array}{l}U_{g g}^{* 6} \\
\mathrm{~m} / \mathrm{s}\end{array}$ & $\begin{array}{l}T_{\mathrm{g}_{1}^{*}}^{*_{4}} \\
\mathrm{~K}\end{array}$ & $\begin{array}{l}T_{\mathrm{ge}}^{*_{4}} \\
\mathrm{~K}\end{array}$ \\
\hline (a) & $\begin{array}{l}\text { Straight- } 7.8^{* 1} \\
\text { (on the market) }\end{array}$ & 0 & \multirow{6}{*}{7.8} & 7.8 & \multirow{6}{*}{76.2} & 67.3 & 0 & \multirow{6}{*}{0.424} & 0.245 & \multirow{6}{*}{500} & 1055 & 44.0 & - & 1.44 & 930 & 1339 & \multirow{6}{*}{3025} & 2832 \\
\hline (b) & Div. $2.6-7.8-8.5^{* 2}$ & 2.6 & & 8.5 & & & & & 0.136 & & 1407 & 35.0 & - & 1.73 & 897 & 1551 & & 2621 \\
\hline (c) & Div. $4.6-7.8-9^{* 2}$ & 4.6 & & 9.0 & & & & & 0.108 & & 1514 & 32.5 & - & 1.86 & 884 & 1664 & & 2540 \\
\hline (d) & Div. $6.4-7.8-9.5^{* 2}$ & 6.4 & & 9.5 & & 52.3 & 15.0 & & 0.0892 & & 1597 & - & 37.5 & 1.64 & 873 & $(1432)$ & & 2470 \\
\hline (e) & Div. $8.4-7.8-10^{* 2}$ & 8.4 & & 10.0 & & & & & 0.0750 & & 1666 & - & 41.0 & 1.52 & 862 & $(1310)$ & & 2407 \\
\hline (f) & Div, $12.2-7.8-11^{* 2}$ & $\overline{12.2}$ & & 11.0 & & & & & 0.0553 & & 1775 & - & 42.5 & 1.48 & 844 & (1249) & & 2297 \\
\hline
\end{tabular}

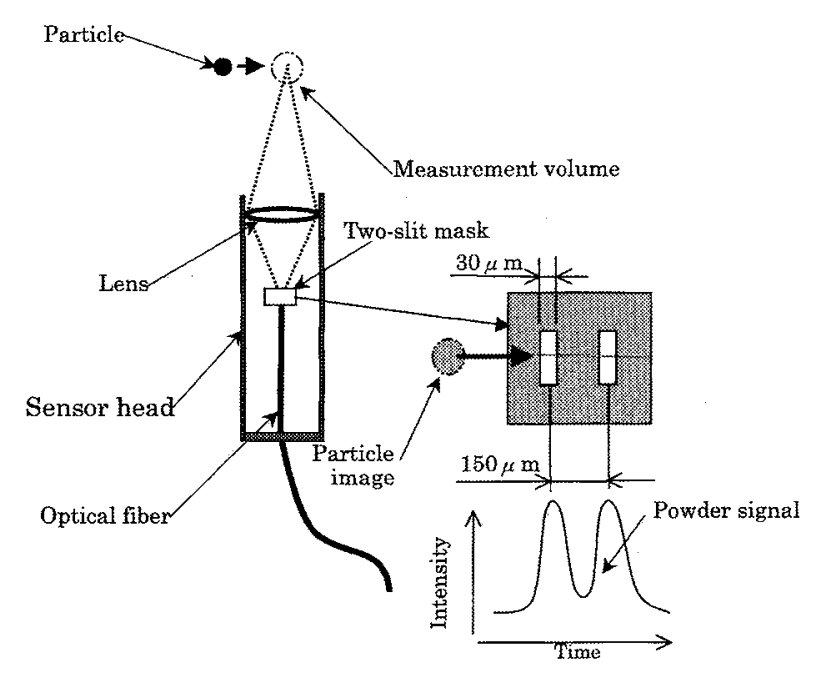

Fig. 2 Schema of the sensor head with the two-slit optical mask.

を溶射粒子の放射光が通過する際に検出された信号のピーク 間隔の時間(Fig. 2)で両スリット間距離を除して求める。粒 子表面温度は, 二色式温度測定原理により二つの異なる波長 $(792,995 \mathrm{~nm})$ の放射光を検出し，先の放射強度比を用いて 算出する．粒子径は，検出した放射光の強度が粒子温度とそ の表面積に比例することから求められる。

実際の HVOF 溶射に衫いては，ノズル出口部付近ではフ レームが明るすぎて溶射粒子の放射光との分離ができず測定 は不可能であったため, 溶射距離と同じノズル出口より 200 $\mathrm{mm}$ の位置に执いてフレーム中心軸付近の粘子の挙動を解析 した.

\section{5. 溶射皮膜の評価方法}

溶射皮膜は, 表面拉上び断面の組織の SEM 観察, X 線回 折火上る構造解析, 皮膜断面の微小ビッカース硬度(荷重 $2.942 \mathrm{~N})$ 飞より評価した。さらと, 化学組成分析は,
EPMAの定量分析炕よりビーム径(測定領域の直径)を 50 $\mu \mathrm{m}$ として皮膜断面の 5 籄所を測定し，その值を平均して求 めた。

溶射皮膜の基材との密着性はJIS H 8666 を参考に測定し た。すなわち, 円筒ブロック(材質 $\mathrm{SS} 400, \phi 30 \mathrm{~mm}$, 長さ $40 \mathrm{~mm}$ ) 端面に皮膜(膜厚 : 約 $0.25 \mathrm{~mm}$ ) 老溶射し, その上飞 もらひとつのブロックをエポキシ樹脂接着剤(チバ・スペン ヤルティ・ケミカルズ製，アラルダイトAT-1)で接着した 試験片をクロスへッド速度 $1 \mathrm{~mm} / \mathrm{min}$ で引張試験し, 溶射 皮膜の公称破断応力を求め, 密着力とした。

溶射パターンの検討は, ガン移動を $25 \mathrm{~mm} / \mathrm{s}$ と低速にし て，同一直線上を四往復させて作製した皮膜に対し，その皮 膜厚さの分布をダイヤルダージを用いて測定して行った．溶 射効率は，30秒間に堆積した皮膜質量を供給した溶射材料 粉末の質量で除して求めた.

\section{III. 数值シミュレーション ${ }^{(9)(12)}$}

上述の実験に対して，筆者らが作成した数值シミュレーシ ョンにより，ノズル内のみで惊るが燃焼がス拉よび溶射粒 子の挙動について検討した，以下に，その概要を述べる.

ノズル内の燃焼ガスは, 半理想気体(その物性值は温度に のみ依存して变化する)で，その流れは準一次元定常等エン トロピーと仮定した。溶射粒子は, 流体からの抗力のみを受 け，重力扔よび粘子間の干渉は無視した。また，その粒子の 供給量は少ないので，燃焙ガスに及注す粒子の影響を無視し た.ささら，溶射粒子は球形，その比熱，密度は一定で，半 径方向に温度分布は無い之仮定した。

これらの仮定の下で，溶射粒子の加速と加熱の過程は，以 下の運動方程式 (1) と熱伝達方程式 (2)を解くことにより 解析できる。

$$
\frac{4 \pi}{3}\left(\frac{D_{\mathrm{p}}}{2}\right)^{3} \rho_{\mathrm{p}} \frac{\mathrm{d} U_{\mathrm{p}}}{\mathrm{d} t}=\pi\left(\frac{D_{\mathrm{p}}}{2}\right)^{2} C_{\mathrm{D}} \rho_{\mathrm{g}} \frac{\left|U_{\mathrm{g}}-U_{\mathrm{p}}\right|\left(U_{\mathrm{g}}-U_{\mathrm{p}}\right)}{2}
$$

ここで, $D_{\mathrm{p}}$ : 溶射粒子直佳, $\rho_{\mathrm{g}}$ : 燃焼ガスの密度, $\rho_{\mathrm{p}}$ : 溶 
射粒子密度, $U_{\mathrm{g}}$ ：燃焼ガス速度， $U_{\mathrm{p}}$ : 溶射粒子速度， $C_{\mathrm{D}}$ は 抗力保数(14)でレイノルズ数 $R_{\mathrm{e}}$ の関数で每る.

$$
\frac{4 \pi}{3} \rho_{\mathrm{p}} c_{\mathrm{p}}\left(\frac{D_{\mathrm{p}}}{2}\right)^{3} \frac{\mathrm{d} T_{\mathrm{p}}}{\mathrm{d} t}=4 \pi\left(\frac{D_{\mathrm{p}}}{2}\right)^{2} h\left(T_{\mathrm{g}}-T_{\mathrm{p}}\right)
$$

ここで, $T_{\mathfrak{g}}$ : 燃焼ガス温度, $T_{\mathrm{p}}$ : 溶射粒子温度, $c_{\mathrm{p}}$ : 溶 射粒子比熱, $h$ : 熱伝達係数 ${ }^{(15)}$ はヌセルト数 $N_{\mathrm{u}}$ の関数であ る.

溶射粒子温度 $T_{\mathrm{p}}$ が, 融点 $T_{\mathrm{MP}}$ に達した場合, それ以後 の入熱量 $Q$ の積算值を, 粒子一つ西たりの融解潜熱 $Q_{\mathrm{L}} て ゙$ 除した值を溶融の度合い $\Sigma Q / Q_{\mathrm{L}}(\%)$ として評価する。ここ で，溶融の度合いは市くまです入熱量の目安としての指標 で，仮にこの值が50\%であっても，粒子が半分溶融してい るわけではない，李た，実際ては，粒子内では温度勾配があ り，そして表面では溶融，気化，酸化など複雑な現象が生じ ていると考光られるが，本解析でをれれでは扱っていない，

\section{N． 結果および考察}

\section{1. 数値シミュレーション結果}

実験を考察するうえで有益な情報を得られることができる ので，あらかじめFig. 3, Fig. 4 斿よび Table 2 に, HVOF 溶射のノズル内に拉仔る燃焼ガスと粒子の状態についての数 值シミュレーション結果の一例を示す。溶射粒子は, Ni-20 mass $\% \mathrm{Cr}$ 合金(密度 $\rho_{\mathrm{p}}: 8300 \mathrm{~kg} / \mathrm{m}^{3}$, 融点 $T_{\mathrm{MP}}: 1693 \mathrm{~K}$, 比熱 $c_{\mathrm{p}}: 444 \mathrm{~J} /(\mathrm{kg} \cdot \mathrm{K})$, 融解潜熱 $\left.L: 300 \mathrm{~kJ} / \mathrm{kg}\right)$ で, 粒径 を平均の $24 \mu \mathrm{m}$ とした。なお，本計算では，実験に使用乙 た NiCrAlY 合金の物性値の一部が不明であったため, 組成 の類似した $\mathrm{Ni}-20$ mass\% $\mathrm{Cr}$ 合金の物性値で代用した。

Fig. 3 中，すべてのノズルに対し，ノズルが末広化される までの軸方向距離 $x=61.2 \mathrm{~mm}$ まではノズル形状が変化しな いため，燃焼ガスと粒子の状態はすべて同一であり，その後 の末広部で差異を生じる．これは、ノズル内のガスの流机が 出口部で变化を生じても，流れが音速を超えているためその 影響が上流にまで及ばないためである(16)。また，燃爟がス はノズルを末広化することにより急激に速度が増加し，圧力 と温度减少する。しかし，末広区間 $l_{\mathrm{d}}$ が $15 \mathrm{~mm}$ と短いた め, Fig. 4 の計算結果が示すように，ズル出口径 $d_{\mathrm{e}}$ の変 化汇伴う粒子の状態(速度 $U_{\mathrm{p}}$ や溶融の度合い $Q / Q_{\mathrm{L}}$ ) の差異 は，ノズル出口部でも顕著でない。若干, Straight-7.8の粒 子の状態は, 他の末広,ズルのそ机より速度 $U_{\mathrm{pe}}$ が小さく,

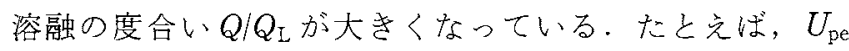
は, 最小の Straight-7.8で $337 \mathrm{~m} / \mathrm{s}$, 最大の Div. 12.2-7.8-11

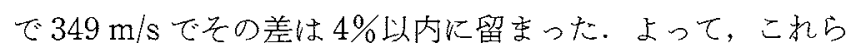
のノズルを使用することで，溶射粒子の挙動や皮膜特性に及 ぼすノズルからのフレームジェットの膨張状態のみの影響が 検討できると判断して実験を行った。

\section{2. ノズル形状とフレームジェットの膨張状態の関係}

Fig. 5 と Fig. 6 に，ノズル出口径 $d_{\mathrm{e}}$ を変化させることに
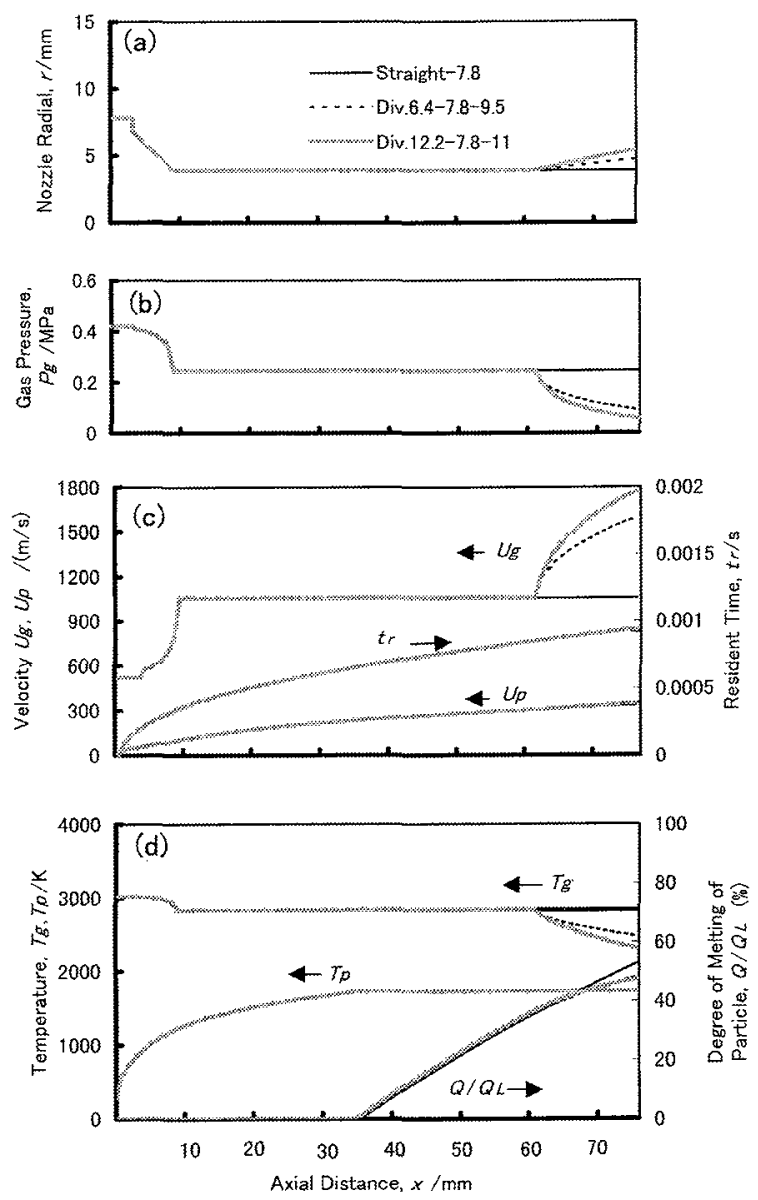

Fig. 3 Results of numerical simulation of HVOF NiCrAIY particle inside the nozzle for three different exit diameter of divergent nozzle; (a) nozzle radial, (b) gas pressure, (c) gas and particle velocity, and resident time of particle, (d) gas and particle temperature, and degree of molten of particle.

よるフレームジェットの膨張状態(溶射粉末は未投入)の変化 之各膨張状態の模式図(17)をそれぞれ示す。膨張状態の变化 は，ノズル出口部圧力 $P_{\mathrm{e}}$ と大気压 $P_{\mathrm{a}}$ の相違により生じるる ので， $d_{\mathrm{e}}$ 大さくするにつれ， $P_{\mathrm{e}}$ が下がり，不足膨張，適 正膨張, 過澎張と变化している。また, フレームはノズル出 口から進むにつれて大気中に拡散し，いずれの膨張状態のフ レームも Fig. 5 の写真ではノズルから $150 \mathrm{~mm}$ 付近では消 失しているよう炕見える。ただし，この搪散の度合いは $P_{\mathrm{e}}$ が低いフレーム汪ど大きいためと考光られ，目視では過彭張 状態のフレームの方が比較的短い噴出距離で確認できなくな った。

設計上は $d_{\mathrm{e}}$ が $9.12 \mathrm{~mm}$ の時, $P_{\mathrm{e}}=P_{\mathrm{a}}(=0.098 \mathrm{MPa})$ とな るが，実際にはがスの粘性による境界層があるため設計值よ り少し大きな径で適正彭張となると考光られる(4)， $d_{\mathrm{e}}=9.5$ mm '場合 (Fig. 5(d))は，幾分過膨張気味であり，この状 態と同図(c)との間で適正膨張になっていると推測される。

Fig. 5(a) (c) の不足膨張状態 $\left(P_{\mathrm{e}}>P_{\mathrm{a}}\right)$ では, Fig. 6(b) 飞. 示すように圧縮波が重なった菱形部分では相詨的に温度が高 


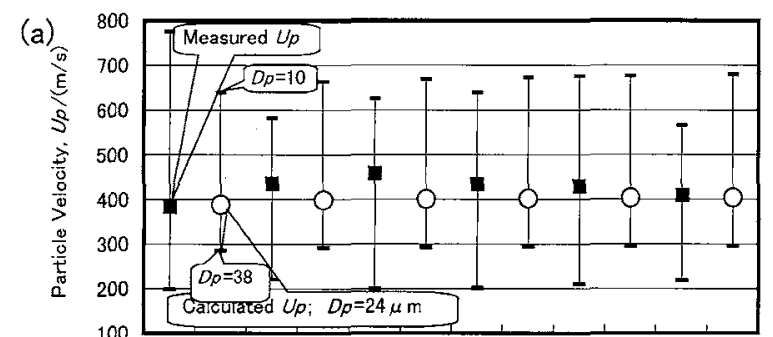

(b)
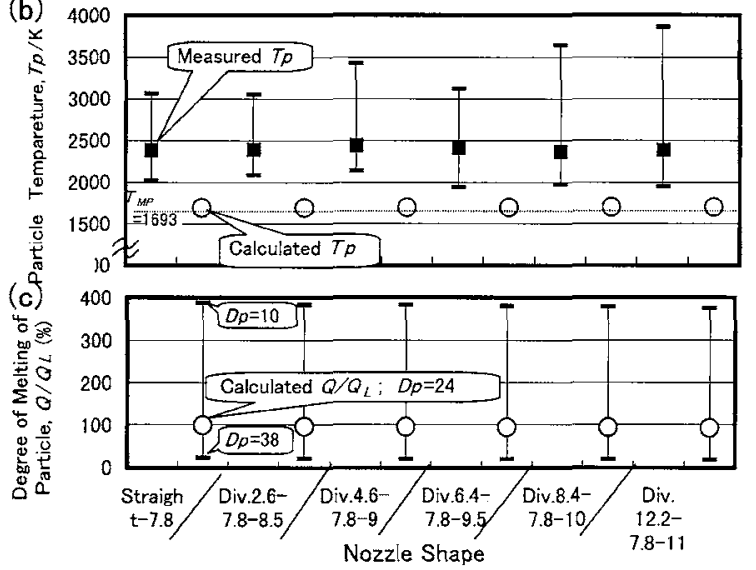

Fig. 4 HVOF sprayed NiCrAlY particle behaviors calculated by numerical simulation at nozzle exit and measured by inflight particle sensor system at spray distance $200 \mathrm{~mm}$ for six different exit diameters and measured of divergent nozzle; (a) particle velocity, (b) particle temperature and (c) the degree of melting of particle.

い光䊧部となり，いわゆるショックダイアモンドが目視され た。ただし，Fig. 5(a)では，不足膨張の程度が著しく，Fig. 6(a)に示すよらに，膨張波や压縮波のほか飞マッハディス クが生じた. Fig. 5(e), (f) では, 噴出直後の流れが縮小し, さらにその最初の三角形が比較的暗いため過膨張状態 $\left(P_{\mathrm{e}}<\right.$ $\left.P_{\mathrm{a}}\right)$ と判断でさる。そして, 斜め衝撃波(Fig. 6(d))が観察さ れた. また, Fig. 5(f)の出口径 $11 \mathrm{~mm} の$ ノズルでは, 急激 な膨張のためノズル出口部で流れが内壁よりはく離して観察 された。

Fig. 6 に抏いて，流れのマッ八数 $M$ とマッ八角などには 以下の関係がある。適正膨張状態(同図(c))のマッ八波の角 $\mu$ ，立たは不足膨張（同図(a)，(b)）の圧縮波执よび膨張波の 波頭および波尾の角度 $\left(\mu_{1}, \mu_{2}\right)$ に対しては式( 3 )が成り立 $\supset^{(18)}$.

$$
\sin \mu=\frac{a}{U_{\mathrm{g}}}=\frac{1}{M}
$$

ここで， $a\left(=\sqrt{\kappa R T_{\mathrm{g}}}\right)$ は音速で，比熱比 $\kappa ，$ ガス定数 $R$ と 温度 $T_{\mathrm{g}}$ の関数である.

また，過膨張状態(Fig. 6(d))の斜め衝撃波では，衝撃波 前の速度 $U_{\mathrm{g} 1}$ (マッ八数 $\left.M_{1}\right)$ の流線は斜め衝撃波を通過する と波面に近づくょうに転向角 $\theta$ で曲げられる。そして，マッ 八数 $M_{1}$ と衝撃角 $\beta$, 転向角 $\theta$ との間に次の関係がある ${ }^{(19)}$.

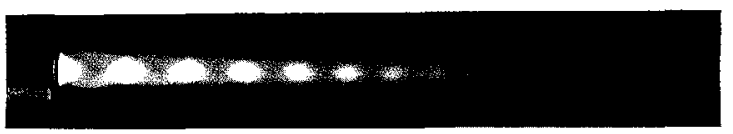

(a) Streight-7.8 (under-expansion)

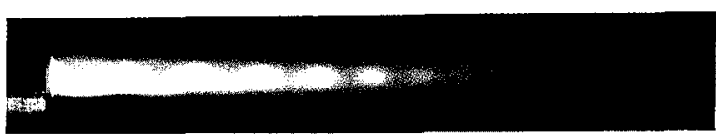

(b) Div. 2.6-7.8-8.5 (under-expansion)

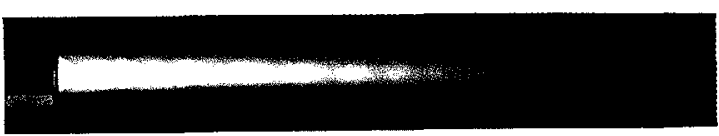

(c)Div. 4.5-7.8-9 (under-expansion)

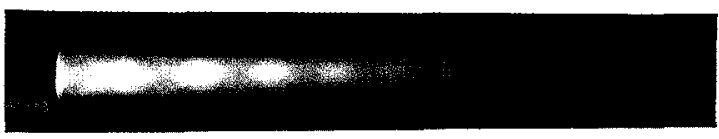

(d)Div.6.4-7.8-9.5 (near-correct -expansion)

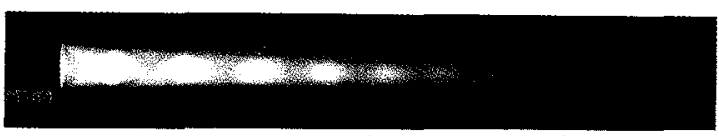

(e) Div. 8.4-7.8-10 (over-expansion)

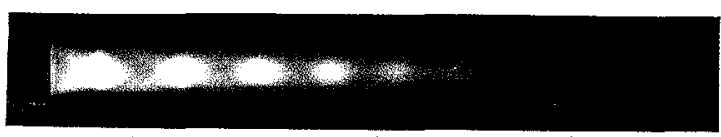

(f) Div. 12.2-7.8-11 (over-expansion)

Fig. 5 Variation in expansion of free jet with nozzle exit diameter. (Without powder, ambient pressure $P_{\mathrm{a}}=0.098 \mathrm{MPa}$ ).

$$
\tan \theta=\frac{2 \cot \beta\left(M_{1}^{2} \sin ^{2} \beta-1\right)}{M_{1}^{2}(\kappa+\cos 2 \beta)+2}
$$

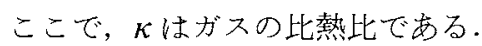

Table 2 に各膨張状熊の噴出後の最初の部分のマッ⿻角东 たは衝撃角 (Fig. 6 の $\mu_{1}$ なな $\beta$ ), 式 $(3) よ り$ 求めたマッ 八数と各ノズル出口部に和仿る音速 $a_{\mathrm{e}}\left(=\sqrt{\kappa R T_{\mathrm{ge}}}\right)$ を乗じて 計算されるガス速度 $U_{\mathrm{gi}}$ を示した。ただし，斜め衝撃波に対 し, 式 (4)Kて $M_{1}$ を求めるには， $\beta$ と $\theta$ があらかじめわか っていなけ礼ばならないが，Fig. 5 からは $\beta$ のみし測定で きないためここでは，衝撃角をマッ八角とみなし，式 (3)より求めたマッ八数を使用して $U_{\mathrm{gj}}$ 算出し参考值とし て示した。

ノズル出口部速度 $U_{\mathrm{ge}}$ と比ベ，不足膨張状態のジェットの 測定位置における速度 $U_{\mathrm{g}}$ 汢大気中で膨張しているため増加 し, 一方, 過膨張状態のジェットの $U_{\mathrm{gj}}$ は, 縮流のため $U_{\mathrm{ge}}$ 飞より低下する。坛，各膨張状態の中では，適正膨張の場 合の $U_{\mathrm{gj}}$ が最大となる。

そして，Fig.6に示すよらに不足膨張なたは過膨張の場合 にはそれらの程度が著しくなるほど，ジェット内で膨張波や 斜め衝撃波を伴って圧力, 速度, 温度などの状態が激しく変 動する(1)ことが，Fig. 5 の写真かららかがえる。 


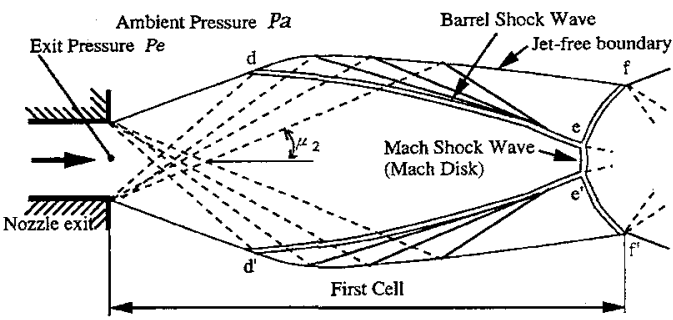

(a) Under Expansion Jet $(P e \gg P a)$

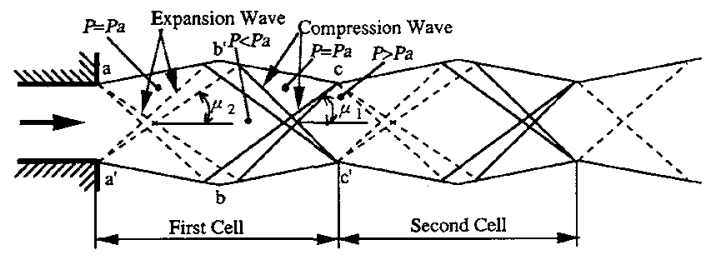

(b) Under Expansion Jet $(P e>P a)$

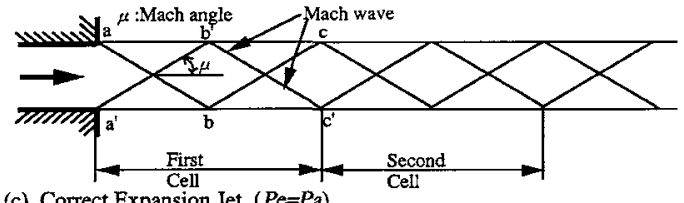

(c) Correct Expansion Jet $(\mathrm{Pe}=\mathrm{Pa})$

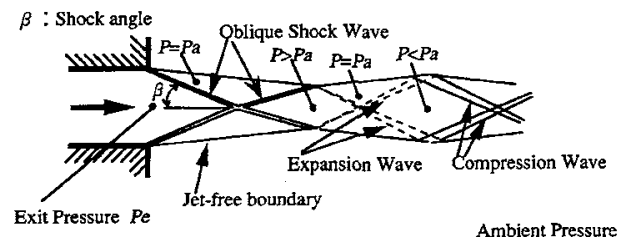

(d) Over Expansion Jet $(\mathrm{Pe}<\mathrm{Pa})$

Ambient Pressure $\mathrm{Pa}$

Fig. 6 Influence of pressure ratio $P_{\mathrm{e}} / P_{\mathrm{a}}$ on expansion jet ${ }^{(17)}$.

\section{3. 溶射飛行粒子挙動に及ぼすフレームの膨張状態}

Fig. 7 K溶射飛行粒子挙動感知評価装置による測定結 果の一例として，円筒ノズル(Straight-7.8)を使用した NiCrAIY 合金溶射に扣忛る粒子の速度と表面温度をそれぞ れ粒子径との関係で示す．測定にあたり，一つの溶射条件に 対し400〜600個ほどの粒子のデータを採取した。

上述の運動方程式 (1), 熱伝達方程式 (2)からもわかる ように，いずれの測定結果においても，Fig.7のように粒子 径 $D_{\mathrm{p}}$ が大きくなるにつれ，速度と温度が下がる傾向があっ た。ここで，表面温度であるが，測定結果は $\mathrm{NiCrAlY}$ 合金 の融点 $1693 \mathrm{~K}$ を超えており，これは高速飛行による加熱， 酸化熱，表層の溶融などの影響が考えられるが，詳細は不明 で検討中である，本報では，測定結果をそのまま示すことに した。

Fig. 4 に溶射粒子の速度 $U_{\mathrm{p}}$, 温度 $T_{\mathrm{p}}$ と溶融の度合い $Q /$ $Q_{\mathrm{L}}$ を示す。ここで，計算結果はノズル出口部に和ける粒子 に関するもので，上限の值が最小粒径 $10 \mu \mathrm{m}$ ，中央值が平 均粒径 $24 \mu \mathrm{m}$, 下限值が最大粒径 $38 \mu \mathrm{m}$ k対する計算結果 である。一方，実测值はノズル出口から $200 \mathrm{~mm}$ の位置に 牤讨る供試溶射粒子 $(10 \sim 38 \mu \mathrm{m})$ に関する結果である。
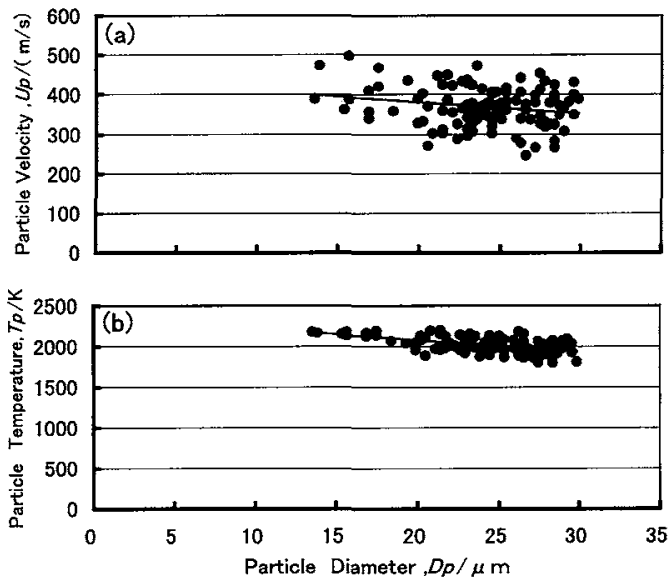

Fig. 7 Correlation between (a) the velocity, (b) the temperature and diameter of HVOF sprayed NiCrAIY particle measured by DPV-2000.

粒子速度 $U_{\mathrm{p}}$ は，ノズル出口部に括ける計算結果ではノズ ル形状による差異はほとんどないが，ノズル出口より200 $\mathrm{mm}$ 下流の位置での実測結果では，出口径 9 9.5 mm 付近 で最大となり，Straight-7.8に比べ約 $40 \mathrm{~m} / \mathrm{s}$ 汇ど高くなっ ている。これはN.2 項で述べたよらに，ノズルから噴出し たフレームジェットが適正膨張となる場合が，衝撃波による フレームの圧力, 速度の急激な変動が少なく, 速度 $U_{\mathrm{gj}}$ が最 大となることが寄与しているためと考えられる。しかし， ズル外に批いてフレームは激しく変化するが, フレームジェ ットが大気中に搪散しその速度と密度が低下していくため， 粒子以及洔すフレームの影響が小さく，粒子速度の著しい差 とはならなかったと推測される。

一方, 粒子温度はジェットの膨張状態による差異はほとん ど確認できない。

\section{4. 皮膜特性に及ぼすフレームジェットの膨張状態の影響}

Fig. 8 に皮膜断面組織の一例を示す.フレームジェット の膨張状態による皮膜組織に顕著な差異はなく，李た，図示 しないが皮膜の表面組織とX 線回折パターンでも同様に差 異は明瞭にはならなかった。

Fig. 9 に(a) 皮膜断面の酸素含有率之硬さ，(b)溶射効率 叔よび(c)基材との密着力を，Fig. 10 に溶射パターンを示 ot.

皮膜断面の酸素含有率と硬さは，各ノズル間で大きな差異 はないが，Straight-7.8の皮膜は酸化の度合いが比較的高 く，硬さも高くなっている。こ㞦は，フレームジェットの膨 張状態の影響子考えられるが，大さな要因はノズル末広部が ないためと考えられる。つまり，前述の Fig. 4 の計算結果 です Straight-7.8 ノズルは溶融の度合いが他より若干高くな ることや，これまでの研究で末広部長さが大きくなるにつれ て硬さと酸化の度合いが抑制さ扎る事実之符合する(11)。

溶射効率はノズル出口径が広がるにつれて向上する傾向が 


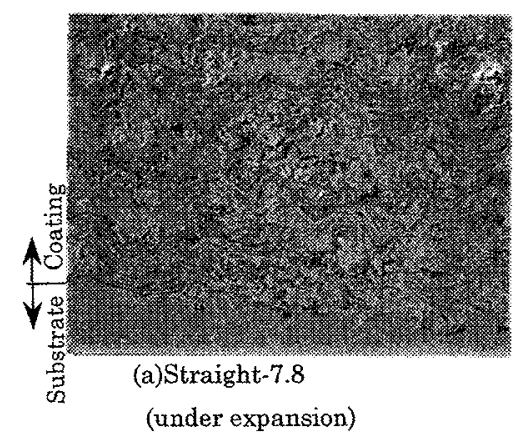

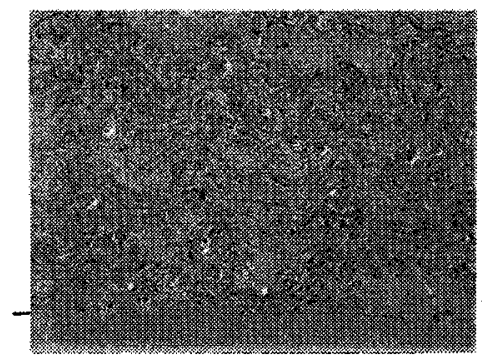

(b)Div.6.4-7.8-9.5

(near correct expansion)

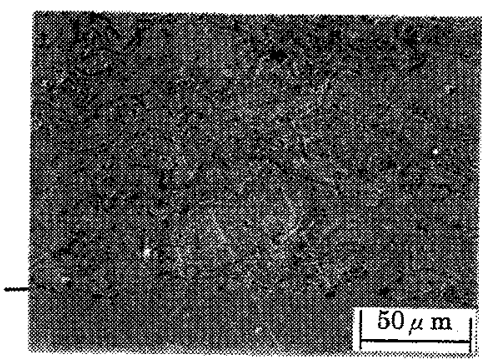

(c)Div.12.2-7.8-11

(over expansion)

Fig. 8 Effect of expansion jet on cross sectional SEM structures of HVOF sprayed NiCrAlY alloy coatings.
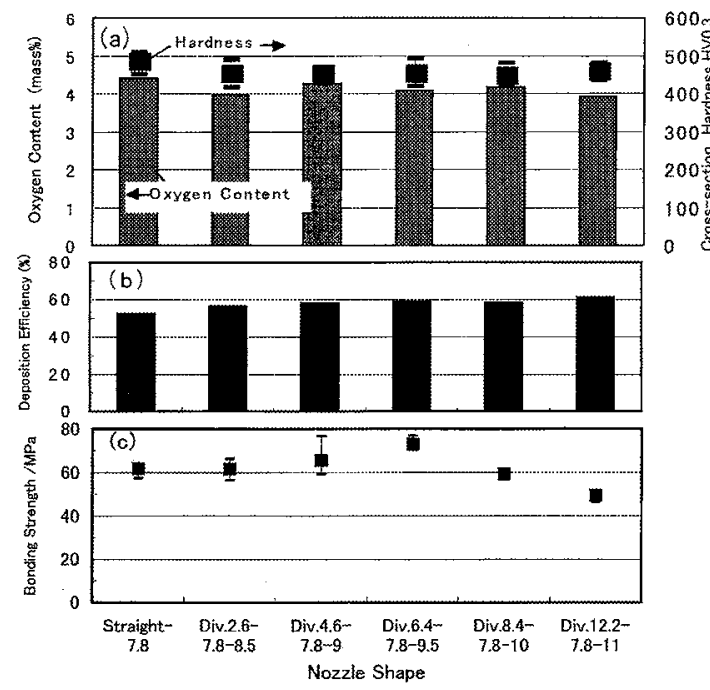

Fig. 9 Effect of exit diameter of divergent nozzle (expansion state of jet) on (a) oxygen content, hardness, (b) deposition efficiency and (c) bonding strength of NiCrAlY alloy coating sprayed by HVOF.

ある. Straight-7.8は酸化の度合いが比較的高いため、この 酸化により結合力の弱い溶射粒子が付着しないため, 溶射効 率が低下すると考完られる。一力，他の末広ノズルでは Fig.9(a)のように酸化の度合い溔が汪とんどないため, 単に酸化のみの影響ではなく，次の原因が考光られる。すな わち，溶射パターン(Fig. 10)をみると，，ズル出口径 $d_{\mathrm{e}}$ が 大きくなるにつれて，皮膜高さ $h_{\mathrm{c}}$ には変化がないが，溶射 帯の幅 $y$ が広がって，断面積が増加している。これは， $d_{\mathrm{e}}$ が広がることによりフレームジェットの径も増加し，これに 伴いフレーム中の粒子の半径方向への分布も広がり, 基材へ の噴射面積が拡大され，粒子間の干渉が少なくなったためと 推測される，このよらに，溶射パターンの変化も溶射効率に 影響を与光ていると考光られる。とはい光， $d_{\mathrm{e}}$ を大きくし すぎるとフレーム流机はノズル内面からはく離し，また大気 への拡散も進むため， $d_{\mathrm{e}}=11 \mathrm{~mm}$ を超えたある程度の $d_{\mathrm{e}}$ で 溶射効率は一定または減少すると考えられる。

基村之の密着力は, 出口径 $d_{\mathrm{e}}=9 \sim 9.5 \mathrm{~mm}$ 付近で最大と

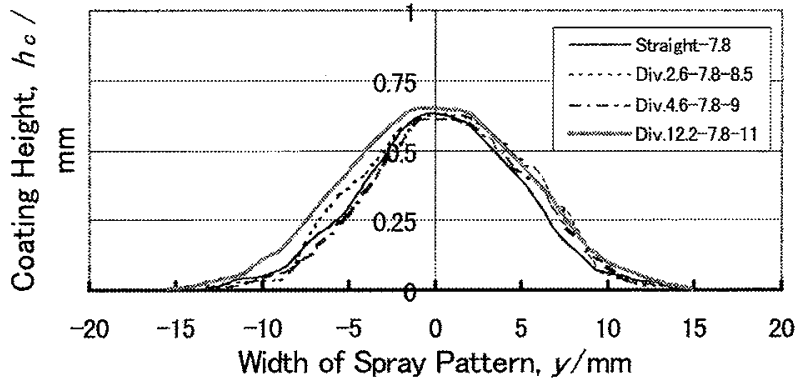

Fig. 10 Effect of exit diameter of divergent nozzle (expansion state of jet) on NiCrAlY alloy spray pattern sprayed by HVOF. (Gun traverse speed: $25 \mathrm{~mm} / \mathrm{s}, 8$ times).

なった，一般に溶射皮膜の密着力の因子としては，粒子に関 しては衝突速度，溶融の度合い，酸化などが，基材汇関して は表面粗さ，温度などが挙げられる。本実験では $d_{\mathrm{e}}=9 \sim$ $9.5 \mathrm{~mm}$ 付近でフレームジェットの適正膨張が得られ，この ことが粒子速度を高め, 衝突エネルギーを大きくし, 密着力 を向上させたと推察される。

以上の結果，燃料执上び酸素の流量を同一之する溶射条件 でHVOF 溶射する場合, フレームジェットを適正膨張の状 態で溶射することが，総合的に良質な皮膜をもたらすと判断 される，さらに，これ采での研究(11) と本報の結果から，， ズル形状について考察すると，のど部以降にノズル末広部長 さを大きくとって円筒部をなくした先細末広ノズル，いわゆ るラバルノズルとし, 出口径 $d_{\mathrm{e}}$ はフレームジェットが啇正 膨張となるようにノズルを設計することが，溶射粒子の速度 をより大きくすることができることがわかった。

近年，溶射粒子を高速化するために燃焼圧力を高くする傾 向がある(3). 本報の結果からより少ない入力エネルギーで効 率的に溶射粒子を加速するためには，ノズル形状をはじめそ れに起因するフレームジェットの膨張状態も考慮する必要の あることが示唆された。

\section{V. 結訔}

本研究で得られた結論は以下のと㜿りである. 
（1）ノズル出口部を末広化した場合，計算結果からノズル 内部に和いて末広部に達するまではフレームの状態に変化は ないが，計算と実験の結果からノズルより噴出したフレーム の状態は出口径が広がるにつれ不足, 適正, 過膨張と変化乙 た。ただし，本実験で採用したノズルでは末広部が $15 \mathrm{~mm}$ と短いため，計算結果からノズル出口部に和忷る溶射粒子の 状態に与える影響は比較的小さかった。

（2）フレームの速度は，計算結果からノズル出口部では過 膨張の場合が大さい。しかし，フレームがノズルより噴出す ると急激にその状態が変化し，ノズル出口から $10 \mathrm{~mm}$ 付近 で写真撮影したフレームジェットのマッハ角より算出したそ

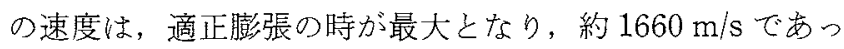
た。

（3）溶射粒子の速度は，異なる出口经のノズルであっても ノズル出口部では計算結果によるとほとえど差はなかった。

しかし，ノズル出口から前方 $200 \mathrm{~mm}$ で測定した結果，粒 子速度はフレームジェットの膨張状態の影響を受け，適正膨 張の時に最大となり, 平均速度で約 $450 \mathrm{~m} / \mathrm{s}$ に達した。

（4）フレームジェットの膨張状態は，皮膜の組織，X線 回折結果，硬さ和よび酸化の度合いには大きな影響を与えな かった，しかし，皮膜と基材間の密着力は，粒子速度が最大 となる適正膨張状態付近の時に最大となった。

（5）溶射効率は，出口径が大きくなるにつれて増加した。

(6) フレームジェットを適正膨張の状態で溶射することに より，総合的に良い皮膜が得られと考兄られる。

終わりに，本研究を進めるにあたり Jet Kote TM II 装置を 貸与いただきご協力を賜った昭和電工秼)と元同社 白井勝之 氏(現，ローデル・ニッタ)ならびに溶射飛行粒子感知評価装
置を貸与いただきご協力を賜ったプラズマ技研工業㧣) 深沼 博隆社長と佐々木正樹氏に深く感謝致します。また，高速噴 流の解析にご助言を賜った九州大学総合理工学研究科 宮里 義昭博上に心より礼を申し上げます。さらに，この実験に 協力いただいた信州大学工学部生産システム工学科卒業研究 生の服部一真君, 伊藤暢洋君, 中嶋俊雄君に感謝します.

\section{文献}

(1) M. L. Thorpe and H. J. Richter: Proc. 13 th International Thermal Spray Conf., Orlando, USA, (1992), 137.

（2）谷 和美, 竹内純一, 小林圭史, 碓井建夫：日本金属学会誌, 61(1997), 629 .

(3) G. R. Heath and R. J. Dumola: Proc. 15th International Thermal Spray Conf. Nice, France, (1998), 1495.

（4）例之ば，木村逸郎：口ケッ卜工学, 養賢堂, (1993), 118

（5）溶接学会編：溶接便覧，丸善，(1990), 656 .

（6）例兑以゙，松尾一泰：圧縮性流体力学，理工学社，(1994)，73.

（7）䅨 和彦, 清水保雄: 溶射技術, 産報出版, 17-1(1997)，20。

(8) C. M. Hackett and G. S. Settle: Proc. $5^{\text {th }}$ National Thermal Spray Conf., Anaheim, USA, ASM International, (1995), 135.

（9）榊 和彦, 清水保雄, 斉藤信克, 合田祥昭: 曰本溶射拹会誌, 34(1997), 1.

（10）棉 和彦, 清水保雄, 合田祥昭: 日本溶射協会第64回全国講 演大会講演論文集, (1996), 45 .

(11) K. Sakaki, Y. Shimizu, Y. Gouda and A. Devasenapathi: Proc. $15^{\text {th }}$ International Thermal Spray Conf. Nice, France, (1998), 445 .

（12）清水保雄, 棉 和彦: 日本溶射協会誌, 35(1998), 13.

(13) P. Gougeon, C. Moreau, V. Lacasse, M. Lamontagne, I. Powell and A. Bewsher: Advanced processing Techniques Particle materials, $\boldsymbol{6}$ (1994), 199.

(14) R. Clift, J. R. Grace and M. E. Weber: Bubbles, Drops and Particles, Academic Press, (1987)

（15）例えば，日本機械学会編：伝熱ハンドブック，丸善，(1993）, 43.

（16）松尾一泰: 王縮性流体力学, 理工学科, (1994), p. 78.

(17) 松尾一泰: 压縮性流体力学, 理工学科, (1994), p. 255, 284.

（18）松尾一泰: 圧縮性流体力学, 理工学科, (1994), p. 34 .

(19) 松尾一泰: 压縮性流体力学, 理工学科, (1994), p. 267. 